\title{
Native and invasive alien anuran species in urbanized areas in Davao City, Philippines, with preliminary study of feeding biology
}

\author{
Jacky Roselle D. GERSAVA ${ }^{1}$, Reynaldo G. ABAD ${ }^{1,2,3}$, Fritzie A. CAMINO ${ }^{1}$, Mae A. RESPONTE ${ }^{1,2}$, \\ Marion John Michael M. ACHONDO ${ }^{1,2}$, Lief Erikson D. GAMALO ${ }^{* 1,2}$ \\ ORCID: 0000-0003-0392-5730; 0000-0002-2136-2612; 0000-0003-2489-4064; 0000-0001-5921-6146; 0000-0002- \\ 5438-0585; 0000-0002-1353-0591
}

${ }^{1}$ Department of Biological Sciences and Environmental Studies, University of the Philippines Mindanao, Mintal,

Tugbok District, Davao City, Philippines

${ }^{2}$ Wildlife-Human Interaction Studies, Ecological Research, and Biodiversity Conservation Laboratory, University of the Philippines Mindanao, Mintal, Tugbok District, Davao City, Philippines

${ }^{3}$ Biology Program, Davao Doctors College, Davao City, Philippines

\begin{abstract}
This article presents the anuran species in urbanized areas, diet overlaps between native and invasive alien anuran species, and its implications on conservation and ecological health in urban environment. Visual encounter technique following the road as a transect was done to determine the diversity of anurans, and stomach content extraction was employed to analyze its diet composition. Results revealed a very low anuran diversity (Shannon-Weiner; 1.165), which is dominated by invasive alien anuran species. Jackknife 1 species richness estimator indicated that 77-100\% of the anuran species in the area were already detected which includes three invasive; Rhinella marina (Linnaeus, 1758), Kaloula pulchra Gray, 1831, Hoplobatrachus rugulosus (Wiegmann, 1834), and two natives; Polypedates leucomystax (Gravenhorst, 1829), Limnonectes leytensis (Boettger, 1893). Additionally, assessing the diet of 33 randomly selected anuran samples revealed that Formicidae dominated their food item. Invasive anurans also showed more diverse diet composition compared to native frogs, in which diet overlaps were observed. In conclusion, the study supports the idea that urbanization decreases anuran diversity and supports the dominance of invasive anurans which compete for food with their native and endemic counterparts. Additionally, it is important to manage invasive anurans that dominates urban ecosystem which might affect the native and endemic species in the area and possibly in nearby pristine environment.
\end{abstract}

Key words: diet composition, diversity, frogs, invasive alien species, roadkills, urban environments

\section{Introduction}

The landscape shifts from rural to urban setting leads to habitat loss as well as change in the local and regional climate affecting most fauna in the area [1]. Since amphibians are sensitive to environmental and ecological changes [1], the negative impact of the changes in the environment caused by urbanization, is more effective compared to other vertebrate groups [2]. However, generalist's anurans, such as invasive alien species, can still thrive in urban areas [3] especially with the presence of suitable habitats, yet little is known about their life histories in urban cities.

As a byproduct of urbanization, the establishment of roads also poses tremendous threats to wildlife species [4]. According to Andrews et al. [5], anurans are one of the most negatively affected taxa due to urbanization. Roads can affect anuran populations in many ways: act as barrier to the individual's movement $[4,6]$, cause habitat fragmentation leading to division of the extant population [4], contaminate habitats due to application of road salt [7], alter the gene pool of a population [8], cause direct mortality due to vehicular collision [9] and increase habitat loss due to physical changes in the environment $[10,11]$.

\footnotetext{
${ }^{*}$ Corresponding author / Haberleşmeden sorumlu yazar: Tel.: +639278021613; Fax.: +639278021613; E-mail: ldgamalo@ up.edu.ph

(C) Copyright 2020 by Biological Diversity and Conservation $\quad$ Received: 31.08.2019; $\quad$ Published: 15.04.2020 BioDiCon. 851-0919
} 
Currently, there are 112 known amphibian species in the Philippines, which includes the six known invasive alien anurans, namely Rhinela marina (Linnaeus, 1758), Hoplobatrachus rugulosus (Wiegmann, 1834), Eleutherodactylus planirostris (Cope, 1862), Hylarana erythraea (Schlegel 1837), Kaloula pulchra Gray, 1831, and Lithobates catesbeianus (Shaw, 1802) [12]. With the persisting rapid growth of urbanization in the Philippines, combined with the global decline of amphibian population, identifying the community structure of amphibians, even in the most disturbed areas, is crucial to mitigate threats for endemic and native species. Moreover, determining their ecology, such as their dietary composition is equally important to understand the life history and the impacts of habitat modifications to anurans in highly urbanized environments. This information can provide implication in the ecological condition of the habitat in terms of the consumer-resource system, and determine sensitiveness of the species towards habitat changes. However, research studies of these types are very limited in the Philippines, especially in the island of Mindanao which is considered as a significant center of amphibian diversity and endemism [13].

Thus, in this study, the roadside community structure of anurans and their diet composition in urbanized areas were evaluated. Moreover, the threats of roads to anurans and the possible ecological competition in terms of diet overlaps between endemic and invasive alien species from the same area were also documented.

\section{Materials and methods}

\subsection{Sampling Site}

The study was conducted in two urbanized areas in Davao City, Philippines, namely Mintal $\left(7.0854^{\circ} \mathrm{N}\right.$, $\left.125.4864^{\circ} \mathrm{E}\right)$ and Tacunan $\left(7.1141^{\circ} \mathrm{N}, 125.5193^{\circ} \mathrm{E}\right)$. These areas are located north of Davao city proper and is at the edge of the expanding Davao City Metropolis. The sampling sites were also selected to represent an urbanized area with differing levels of urbanization based on the population size, type of anthropogenic activities present, abundance of infrastructures, and traffic intensity [14]. The classification of the barangays as urbanized areas was based on the definition given by the Philippine Statistics Office [15], and the urban type based on the paper of Marzluff et al. [16]. Mintal has higher population size [17] and with higher number of commercial buildings compared to Tacunan. Meanwhile, the latter is surrounded by wide residential subdivisions (Table 1).

Table 1. Urban type, human population size and building characteristics of the sampling areas

\begin{tabular}{llll}
\hline Study Sites & Type & Population Size & Buildings \\
\hline Mintal & Urban & 13,227 & $\begin{array}{l}\text { residential houses, university, } \\
\text { commercial spaces, highways }\end{array}$ \\
Tacunan & Sub-urban & & residential houses \\
\hline
\end{tabular}

\subsection{Collection of Samples}

Before the study was conducted, Prior Informed Consents from the Local Government Units of Mintal and Tacunan were acquired. Moreover, gratuitous permit (Permit No.: XI-2018-45), to collect representative specimen was given by the Philippine Department of Environment and Natural Resources Region XI (DENR-XI)

The sampling was conducted between November 2018 and January 2019. For each visit, a total of ten $100 \mathrm{~m}$ road transects coupled with visual encounter method was done in both sides of the road (approximately 2-meter-wide each). Each sampling area was visited four times from 19:00H to 23:00H by four to five people, totaling to 140 man-hours spent and more than 32,000 meters of cemented road traversed for the whole duration of the study.

General information for each specimen were obtained such as the date, place, time, IUCN conservation status, and the description of its microhabitat. Identification of species was aided by the amphibian field guide by Alcala and Brown [18]. The head width, snout-vent length (SVL), tibia length, thigh length, and forearm length were measured using a digital caliper. Afterwards, the animals were released back to their habitats after morphometric analysis, except for those individuals used for diet analysis and some representative voucher specimens.

\subsection{Stomach Content Analysis}

A maximum number of ten (10) individuals from each non-threatened species, as instructed in the gratuitous permit (GP), were used. Specimens were euthanized using the double-pithing method which is considered as an acceptable process of euthanasia for amphibians. The collected stomachs were placed in vials containing $95 \%$ ethyl alcohol for preservation of the stomach contents. The contents of the stomach were observed under a dissecting microscope and identified to the lowest possible taxon. 


\subsection{Data Analysis}

\subsubsection{Species Richness, Abundance, and Diversity}

Jackknife1 was used to estimate the species richness for each sampling area using EstimateS Software Version 9.1.0 [17]. The difference in anuran abundance between Mintal and Tacunan were computed using the Mann-Whitney Utest. In addition, the species diversity was calculated using Shannon-Weiner Diversity Index, Evenness, and Dominance using PAST software Version 1.68 [20].

\subsubsection{Stomach Content Analysis}

Dietary composition was quantified using the frequency of occurrence (FOO) and the degree of food preference (DFP) indexes used in the study of Santos et al. [21]. The frequency of different food items to occur in stomachs of each species was calculated as:

Frequency of Occurrence $=\frac{\text { Number of stomachs an item appeared }}{\text { Total number of stomachs with content }} \times 100$

A particular food item is considered constant if the frequency of occurrence value is more than $50 \%$ for each species, secondary if it is within the range of $25-50 \%$, and accidental if it is observed in less than $25 \%$.

The degree of food preference index was used to infer species consumption of a particular food group [21]. Food items were ranked in each stomach. A maximum value of four (4) was given if it was the only food item present in the stomach. However, for stomachs that contained more than one group of food item, the most abundant was given a value of three (3) while the next most common was given two (2). The least abundant food item was given a value of one (1). The degree of food preference was calculated using the formula:

$\mathrm{DFP}=\mathrm{S}(i) / \mathrm{N}$

where $\mathrm{S}(i)$ indicates the sum of the values of the $i$ or the food group present in the stomach. Meanwhile, $\mathrm{N}$ is the number of stomach analyzed per species. After the DFP values were obtained, it was then classified into four categories: highly preferential $(3<\mathrm{DFP}<4)$, preferential $(2<\mathrm{DFP}<3)$, secondary $(1<\mathrm{DFP}<2)$ or occasional $(0<\mathrm{DFP}<1)$.

\section{Results}

\subsection{Species Richness, Abundance, and Diversity}

Low taxonomic representation of anurans is evident in this study, with only five species collected namely: Hoplobatrachus rugulosus (Wiegmann, 1834), Kaloula pulchra Gray, 1831, Limnonectes leytensis (Boettger, 1893), Polypedates leucomystax (Gravenhorst, 1829), and Rhinella marina (Linnaeus, 1758) (Figure 1). Jackknife 1 species richness estimator indicated that $100 \%$ of the anuran species were already detected in Tacunan (4 species), while only $77 \%$ frog species were detected in Mintal ( 5 species), suggesting that it is possible that some species were missed during the sampling. The low species richness of anurans from the study areas are due to environmental modification of the habitat because of urbanization, which does not favor the existence of other species, except those with greater tolerance and adaptability to disturbed environments, such as the introduced anurans observed in this study.

A total of 238 individuals were documented in this study, dominated by R. marina (44.96\%) and K. pulchra (40.34\%). Despite the ability of the endemic L. leytensis and other native anurans such as P. leucomystax to appear in urbanized areas and withstand urbanization, its occurrence is relatively lower compared to the number of invasive species present in the area. Thus, this study showed that invasive anuran species are more common than the native in urban environments.

Despite the minor differences in the areas' ecological landscapes, results showed that Tacunan has higher number of recorded individuals $(63.03 \%)$. When tested statistically, results showed that there were no significant differences between the abundance of each species between sites, except for $K$. pulchra (p-value =0.02) (Figure 2).

With the very low species richness, coupled with the presence of dominant invasive anuran species, the entire Mintal-Tacunan area showed low diversity (Shannon-Weiner;1.165). Mintal area (Shannon-Weiner; 1.183), which is relatively more urbanized, showed higher diversity compared to Tacunan (Shannon-Weiner; 1.038). This is most likely due to the higher species richness and lesser dominance value observed in Mintal (Dominance; 0.3706) compared to Tacunan (Dominance; 0.3988). 

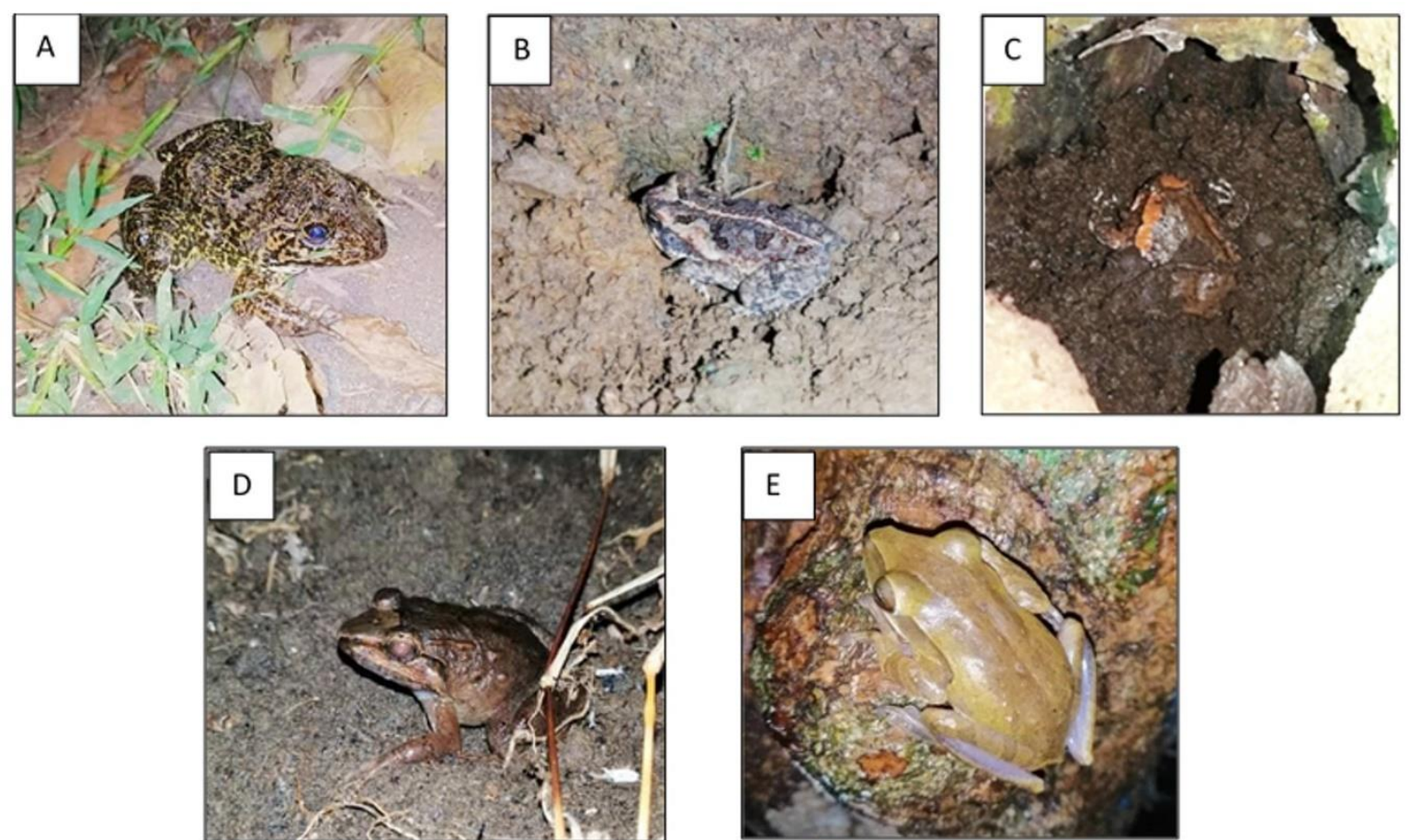

Figure 1. Representative specimens of collected species in Mintal-Tacunan area, Davao City (a) H. rugulosus, (b) R. marina, (c) K. pulchra, (d) L. leytensis, (e) P. leucomystax

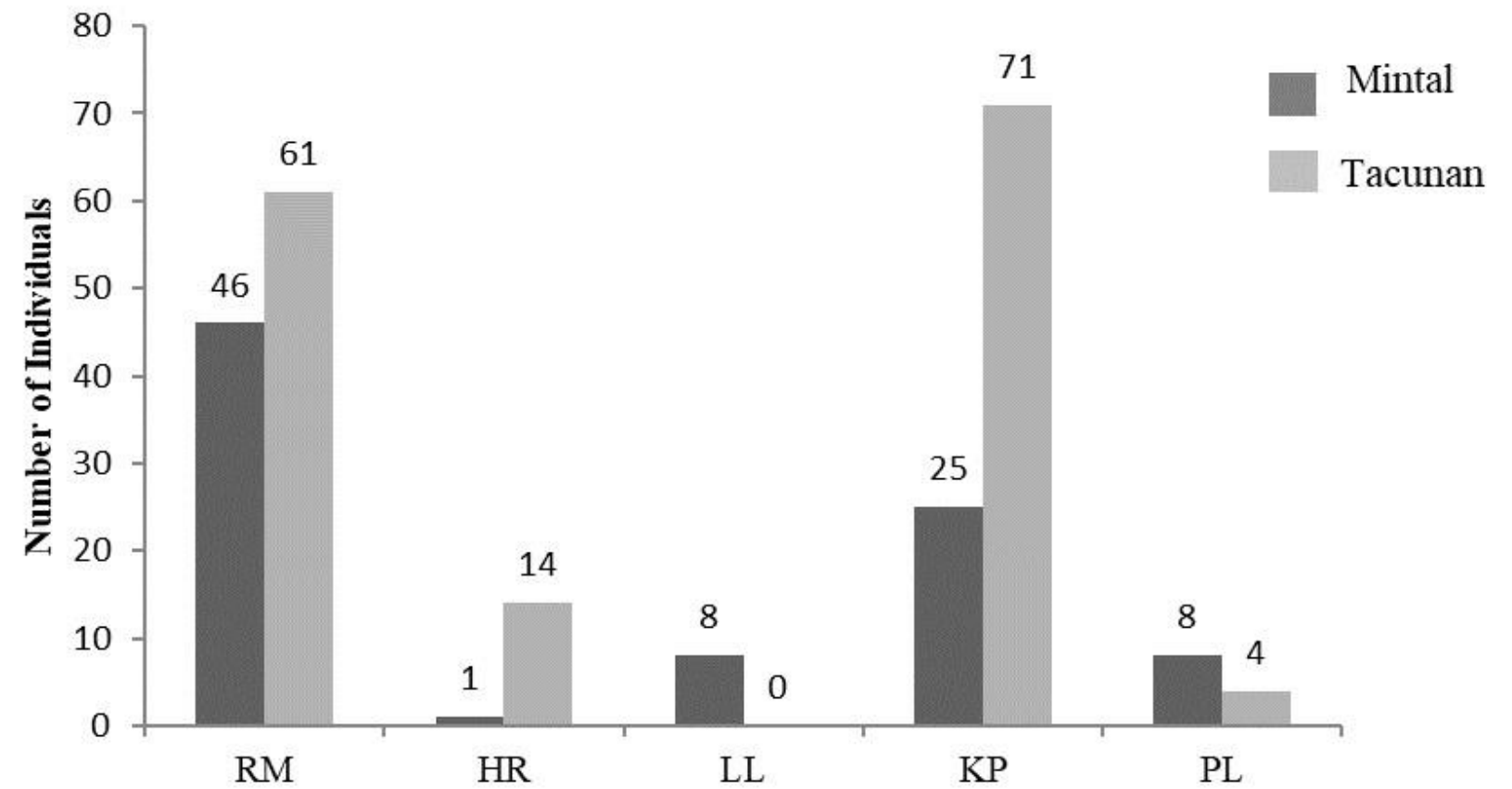

Figure 2. Number of individuals observed per species in Mintal-Tacunan Area. Legend: RM - R. marina; HR - H. rugulosus; LL - L. leytensis; KP - K. pulchra; PL - P. leucomystax

\subsection{Roadkill Documentation}

A total of 28 casualties were recorded for the entire Mintal-Tacunan area. These individuals belong to three invasive anuran species namely; H. rugulosus, $K$. pulchra, and $R$. marina which were documented as mortality from vehicular collisions in roads (observed to have flattened body). K. pulchra and $R$. marina that constitutes $40.3 \%$ and $44.96 \%$, respectively of the population, ranked the highest roadkills. It can also be inferred from Table 2 that $71.43 \%$ of the documented roadkills were from Tacunan. 
Table 2. Anuran Species documented as roadkills collected in Mintal and Tacunan in Davao City, Davao del Sur, Philippines

\begin{tabular}{lccc}
\hline \multirow{2}{*}{ Species } & \multicolumn{3}{c}{ Number of Roadkills } \\
& Mintal & Tacunan & Total \\
\hline Rhinella marina & 6 & 9 & 15 \\
Hoplobatrachus rugulosus & 1 & 0 & 1 \\
Kaloula pulchra & 1 & 11 & 12 \\
TOTAL (\%) & $8(28.57)$ & $20(71.43)$ & 28 \\
\hline
\end{tabular}

\subsection{Diet Composition}

Out of the 238 individuals documented in this study, only 33 stomachs were analyzed. K. pulchra and $R$. marina were the only species that reached the maximum number of ten individuals. Less than ten stomachs were analyzed for the remaining three species due to problems of capturing mature individuals. Three out of the 33 analyzed stomachs were empty (Table 3).

A total of 21 food items were observed, which was further grouped into four general categories; invertebrates, plant material, non-living matter, and unidentified. Inclusive to these categories are 18 taxa of invertebrates, leaves and stalks of unspecified plants, grain of rice, scraps of plastics, and fragmented rocks. The unidentified category includes food items that consists of digested parts of invertebrates based on its visual attributes and texture.

Table 3. Frequency of Occurrence of food items and Degree of Food Preference of anuran species in Mintal-Tacunan area, Davao City, Philippines

\begin{tabular}{|c|c|c|c|c|c|c|c|c|c|c|}
\hline \multirow[b]{2}{*}{ Food Items } & \multicolumn{2}{|c|}{ Hr (2) } & \multicolumn{2}{|c|}{ Kp (10) } & \multicolumn{2}{|c|}{ LI (5) } & \multicolumn{2}{|c|}{ PI (6) } & \multicolumn{2}{|c|}{$\operatorname{Rm}(\mathbf{1 0})$} \\
\hline & $\begin{array}{c}\text { FOO } \\
(\%)\end{array}$ & DFP & $\begin{array}{c}\text { FOO } \\
(\%)\end{array}$ & DFP & $\begin{array}{c}\text { FOO } \\
(\%)\end{array}$ & DFP & $\begin{array}{c}\mathrm{FOO} \\
(\%)\end{array}$ & DFP & $\begin{array}{c}\mathrm{FOO} \\
(\%)\end{array}$ & $\overline{D F P}$ \\
\hline \multicolumn{11}{|l|}{ Invertebrates } \\
\hline \multicolumn{11}{|l|}{ Phylum Arthropoda } \\
\hline \multicolumn{11}{|l|}{ Class Insecta } \\
\hline \multicolumn{11}{|l|}{ Order Hymenoptera } \\
\hline Family Formicidae & $100^{\mathrm{Co}}$ & $1.5^{\mathrm{S}}$ & $70^{\mathrm{Co}}$ & $1.9^{\mathrm{S}}$ & $75^{\mathrm{Co}}$ & $1.8^{\mathrm{S}}$ & $100^{\mathrm{Co}}$ & $3.2^{\mathrm{Hp}}$ & $40^{\text {So }}$ & $1.2^{\mathrm{S}}$ \\
\hline \multicolumn{11}{|l|}{ Order Blattodea } \\
\hline Family Kalotermitidae & & & $50^{\mathrm{S}}$ & $1.7^{\mathrm{S}}$ & & & & & $20^{\mathrm{A}}$ & $0.7^{\mathrm{O}}$ \\
\hline \multicolumn{11}{|l|}{ Family Blattidae } \\
\hline Periplaneta americana & & & $10^{\mathrm{A}}$ & $0.1^{\mathrm{O}}$ & & & & & $10^{\mathrm{A}}$ & $0.3^{\mathrm{O}}$ \\
\hline \multicolumn{11}{|l|}{ Order Coleoptera } \\
\hline Family Curculionidae & & & $20^{\mathrm{A}}$ & $0.7^{\mathrm{O}}$ & & & & & & \\
\hline Family Scarabaeidae & & & $*$ & $*$ & & & & & & \\
\hline Family Erotylidae & & & $10^{\mathrm{A}}$ & $0.1^{\mathrm{O}}$ & & & $10^{\mathrm{A}}$ & $0.2^{\mathrm{O}}$ & & \\
\hline Unidentified Coleoptera & & & $*$ & $*$ & & & & & & \\
\hline \multicolumn{11}{|l|}{ Order Hemiptera } \\
\hline \multicolumn{11}{|l|}{ Family Reduviidae } \\
\hline Melanolestes sp. & & & $10^{\mathrm{A}}$ & $0.4^{\mathrm{O}}$ & $10^{\mathrm{A}}$ & $0.25^{\mathrm{O}}$ & & & & \\
\hline Family Pentatomidae & & & $*$ & $*$ & & & & & & \\
\hline Order Dermaptera & & & $10^{\mathrm{A}}$ & $0.2^{\mathrm{O}}$ & & & & & & \\
\hline \multicolumn{11}{|l|}{ Order Orthoptera } \\
\hline Family Gryllotalpidae & & & & & & & & & $10^{\mathrm{A}}$ & $0.2^{\mathrm{O}}$ \\
\hline Family Acrididae & & & $10^{\mathrm{A}}$ & $0.1^{\mathrm{O}}$ & & & & & & \\
\hline \multicolumn{11}{|l|}{ Order Diptera } \\
\hline maggots & & & $10^{\mathrm{A}}$ & $0.4^{\mathrm{O}}$ & & & & & & \\
\hline Class Chilopoda & & & $10^{\mathrm{A}}$ & $0.1^{\mathrm{O}}$ & & & & & $10^{\mathrm{A}}$ & $0.2^{\mathrm{O}}$ \\
\hline \multicolumn{11}{|l|}{ Class Diplopoda } \\
\hline \multicolumn{11}{|l|}{ Order Spirobolida } \\
\hline \multicolumn{11}{|l|}{ Family Trigoniulidae } \\
\hline Trigoniulus sp. & & & $10^{\mathrm{A}}$ & $0.1^{\mathrm{O}}$ & & & & & $10^{\mathrm{A}}$ & $0.1^{\mathrm{O}}$ \\
\hline \multicolumn{11}{|l|}{ Order Polydesmida } \\
\hline Family Paradoxosomatidae & & & & & & & & & $10^{\mathrm{A}}$ & $0.1^{\mathrm{O}}$ \\
\hline \multicolumn{11}{|l|}{ Class Arachnida } \\
\hline Order Araneae & & & & & & & & & $10^{\mathrm{A}}$ & $0.1^{\mathrm{O}}$ \\
\hline \multicolumn{11}{|l|}{ Phylum Annelida } \\
\hline Class Oligochaeta & & & & & & & & & $10^{\mathrm{A}}$ & $0.4^{\mathrm{O}}$ \\
\hline Plant Matter & $100^{\mathrm{Co}}$ & $1^{\mathrm{O}}$ & $70^{\mathrm{Co}}$ & $1^{\mathrm{O}}$ & $25^{\text {So }}$ & $0.4^{\mathrm{O}}$ & $20^{\mathrm{A}}$ & $0.3^{\mathrm{O}}$ & $60^{\mathrm{Co}}$ & $1.1^{\mathrm{S}}$ \\
\hline Inorganic Material & & & $40^{\text {So }}$ & $0.7^{\mathrm{O}}$ & & & & & $40^{\text {So }}$ & $0.8^{\mathrm{O}}$ \\
\hline Unidentified & $100^{\mathrm{Co}}$ & $0.5^{\mathrm{O}}$ & & & $40^{\mathrm{So}}$ & $0.25^{\mathrm{O}}$ & & & & \\
\hline No. of Empty Stomach & 1 & & & & 1 & & 1 & & & \\
\hline
\end{tabular}




\section{Conclusions and discussion}

The minimal amount of species in this study could support the ideas that species richness and diversity is affected by urbanization $[22,23,24]$. Moreover, the difference in the total abundance of anurans in between sites could be attributed to the difference of their ecological structures, presence/absence of some habitat requirements [24], and the weather conditions when the sampling was conducted. In addition to being less urbanized, light rain was observed in three out of the four sampling visits in Tacunan, which was never observed in Mintal during the study.

Land structure, disturbance level, climatic factors, and the presence of breeding grounds are some of the factors considered in the habitats of anuran population [24]. The presence of these requirements and the characteristics of the urban area affects the occurrence of species [24, 25]. Although anuran diversity in an urbanized area can be sustained by maintaining suitable habitats [24, 26], survival in urban environments is entirely species-specific based on their ecological requirements and the capability of the habitat to provide for these requirements [24]. Despite the differences in the effect of habitat fragmentation to every species, it is necessary to remember that most species exhibit negative correlation with urbanization [25]. Result suggests that all the species documented to inhabit Mintal-Tacunan area could be habitat generalist which have adaptive mechanisms to tolerate habitat alterations [27], which includes an endemic species $L$. leytensis. This data coincides with the report of Delima et al. [28] that L. leytensis is highly adapted to disturbed environments, despite the difference in ecological structure from its natural environment. In addition to L. leytensis, other native frog P. leucomystax can also thrive in urban roadside environment, where both species observed to commonly thrive in vegetated areas along the road. This suggests the need to maintain the existence of green spaces in urban cities.

In addition to habitat disturbance, road collision with vehicles is also one of the threat to the amphibians in urbanized environments. Overall, amphibians have the highest mortality rates from vehicles due to its limited behavioral response and dual habitat requirement [6]. However, each species has differential documented death caused by roadkills due to intrinsic features such as abundance of the species within an area [29]. As what was observed from the study of Matos in 2012 [29], the number of roadkills for each species is in positive correlation with its local abundance. K. pulchra and $R$. marina were also the ones with high range of microhabitats and frequently found beside the road which increases its probability to be involved in road accidents. In addition, species that are more active and must disperse through urban landscape to complete its life cycle, such as K. pulchra and $R$. marina, have higher chance in road-induced accidents [30].

Invertebrates - mostly arthropods - are the most common food group ingested, owing to the fact that most of the Philippine anurans are invertebrate feeders [18]. Crawling and fossorial insects were the most commonly consumed prey since most of the collected anuran species were ground foragers. . pulchra and $R$. marina showed the most diverse invertebrate prey consumption. The wide variety of food items observed in these invasive species indicates that these are generalist and opportunistic feeders [31,32].

Although the analysis was limited using small sample sizes, the results showed that only ants were considered as Constant food items in the diet of most anurans. In terms of the Degree of Food Preference, only ants in the diet of $P$. leucomystax were considered as Highly Preferential, and ranked as Secondary food preference for the remaining four species. The dominance of ants in the diet of frogs was already observed in previous studies $[14,31,32]$. The considerable high amount of this arthropod group in the tropics and the sit-and-wait foraging strategy contributes to the reason why this prey dominates the diet of the anuran species in the urban area [14]. According to Toft [33], tropical anurans have two main diet patterns: "ant specialists and "non-ant specialists". Ant specialist anurans ingest chitinous, slow-moving arthropods, while the non-ant specialists devour larger, less-chitinous, and mobile arthropods [31]. Generally, the results suggest that the anuran species collected in Mintal-Tacunan area are ant-specialists due to the frequency of occurrence, degree of food preference, and limited prey diversity regularly observed in the stomach of the individuals of the collected species. However, the limited number of stomachs subjected to dietary analysis must be considered as it could greatly interfere with the Frequency of Occurrence (FOO) and Degree of Food Preference (DFP) computations.

Moreover, plant matters, either ranked as constant or secondary, were also a frequent consumed food items of anurans, which were also reported in previous studies in the Philippines [32, 34]. The occurrence of plant materials in the diet of anurans could be incidental due to the close association of the habitat of its prey to patches of vegetation leading to accidental ingestion of plant matters. However, according to Santos et al. [21], the presence of plant materials provides valuable information on the feeding behavior of anurans. Studies also showed that the presence of plant in the diet possibly aids in the elimination of parasites, provides nutrients, and an additional source of water to anurans [32, 35].

Results on the diet analysis showed an overlapping of prey items between the native and the introduced invasive species in highly urbanized areas. This indicates possible competition towards food resources that might potentially harm the presence and abundance of endemic (e.g. L. leytensis) and/or the native species (e.g. P. leucomystax) which could contribute to their decreasing population trends. Though some studies have shown that dietary overlaps between invasive and native anuran species could not reduce the abundance of the latter $[36,37]$, this study suggests that in a highly urbanized area, the anuran community is dominated by more adaptable invasive species with relatively higher range of diet composition. This could possibly affect endemic anurans and also other local organisms within the urban ecosystem. 


\subsection{Conservation and Ecosystem Health Implications}

With some suitable habitats remaining, anurans can still thrive in disturbed habitats even in a highly urbanized environment. In the case reported in this study, native and endemic frogs are still present in urban areas in Davao City which were frequently observed in vegetated areas (e.g. gardens) alongside the road. With the increasing urbanization throughout the Philippines, urban planning should consider conserving suitable habitats and even increase habitat complexity.

With the dominance of invasive anurans in urban habitats and their diet competition with their native counterparts, proper management should be done to avoid further dispersal of these alien species. Aside from diet competition, the high abundance of these invasive species may result in parasite transfer to other native species in the area. Moreover, one of the dominant invasive species $R$. marina observed in this study, produces bufotoxin which can kill native predators and domesticated animals [38] which do not have any natural defense against the potent toxin.

Furthermore, this study finds no proof that $R$. marina preys on mosquito or their larvae in urban cities. The practice of intentional release of this species in a city in the Philippines to eradicate dengue mosquito [39] might give more problems in urban ecosystems and in nearby pristine environments. Identifying the threats to amphibians (in this case the dominance of invasive alien species) even in the most disturbed environments is one way to produce conservation initiatives and mitigate the rapid extinction of amphibians worldwide.

\section{Acknowledgements}

The researchers would like to thank the Philippine Department of Environment and Natural Resources Region XI (Permit No.: XI-2018-45), and the Local Government Units of Mintal and Tacunan for the permit to conduct the study. The researchers are also grateful to the following people for the support during the sampling;. Kristian James Suetos, Brian Sabanal, Jasmin Alojado, Kublai Jabon, and Mrs. Grace C. McManus.

\section{References}

[1] Vershinin, V. L., Vershinina, S. D., Berzin, D. L., Zmeeva, D. V., \& Kinev, A. V. (2015). Long-term observation of amphibian populations inhabiting urban and forested areas in Yekaterinburg, Russia. Scientific data, 2, 150018.

[2] Mazgajska, J. \& Mazgajski, T.D. (2010). Amphibians of Poland's Urban Areas. Preface. Museum and Institute of Zoology, PAS.

[3] Hoefer, A. M. \& Starrs, D. (2016) One pond fits all? Frogs as an indicator of urban wetland health. Final Report to Upper Murrumbidgee Waterwatch. Ginninderra Catchment Group, Canberra.

[4] Forman, R. T., \& Alexander, L. E. (1998). Roads and their major ecological effects. Annual review of ecology and systematics, 29(1), 207-231.

[5] Andrews, K. M., Gibbons, J. W., Jochimsen, D. M., \& Mitchell, J. (2008). Ecological effects of roads on amphibians and reptiles: a literature review. Herpetological Conservation, 3, 121-143.

[6] Beebee, T. J. (2013). Effects of road mortality and mitigation measures on amphibian populations. Conservation Biology, 27(4), 657-668. 4

[7] Duff, J. P., Colvile, K., Foster, J., \& Dumphreys, N. (2011). Mass mortality of great crested newts (Triturus cristatus) on ground treated with road salt. Veterinary Record, 168(10), 282-282.

[8] Johansson, M., Primmer, C. R., Sahlsten, J., \& Merilä, J. (2005). The influence of landscape structure on occurrence, abundance and genetic diversity of the common frog, Rana temporaria. Global Change Biology, 11(10), 1664-1679.

[9] Mazerolle, M. J. (2004). Amphibian road mortality in response to nightly variations in traffic intensity. Herpetologica, 60(1), 45-53.

[10] Sillero, N. (2008). Amphibian mortality levels on Spanish country roads: descriptive and spatial analysis. AmphibiaReptilia, 29(3), 337-347.

[11] Eksilmez, H., Altunışık, A., \& Özdemir, N. (2017). The Herpetofauna of Karçal Mountains (Artvin/Turkey). Biological Diversity and Conservation 10(1), 1-5.

[12] Diesmos, A.C., Watters, J.L., Huron, N.A., Davis, D.R., Alcala, A.C., Crombie, R.I., Afuang, L.E., Gee-Das, G., Sison, R.V., Sanguila, M.B. and Penrod, M.L. (2015). Amphibians of the Philippines, part I: checklist of the species. Proceedings of the California Academy of Sciences, 62(20), pp.457-539.

[13] Diesmos, A. C., \& Brown, R. M. (2011). Diversity, biogeography, and conservation of Philippine amphibians. In Biology and Conservation of Tropical Asian Amphibians. Proceedings of the Conference "Biology of the Amphibians in the Sunda Region, South-east Asia.' Institute of Biodiversity and Environmental Conservation, Universiti Malaysia Sarawak, Kota Samarahan, Sarawak, Malaysia (pp. 26-49).

[14] Yap, C.H. (2015). Diet of five common anurans found in disturbed areas in northern peninsular Malaysia (dissertation) Universiti Sains Malaysia. 
[15] Philippine Statistics Office (2010). Urban Barangays in the Philippines [Internet]. Available from https://psa.gov.ph/content/urban-barangays-philippinesbased2010-cph

[16] Marzluff, J. M., Bowman, R., \& Donnelly, R. (2001). A historical perspective on urban bird research: trends, terms, and approaches. In Avian ecology and conservation in an urbanizing world (pp. 1-17). Springer, Boston, MA.

[17] Philippine Statistics Authority (2015). Total Population by Province, City, Municipality and Barangay: as of August 1, 2015 [Internet]. Available from https://www.psa.gov.ph/sites/default/files/attachments/hsd/pressrelease/R12.xlsx

[18] Alcala, A.C., Brown, W.C. (1998). Philippine amphibians. An Illustrated Field Guide. Bookmark. Inc, Makati City, Philippines.

[19] Colwell, R.K. (2013) EstimateS: Statistical estimation of species richness and shared species from samples. Version 9.1.0. http://purl. oclc. org/estimates.

[20] Hammer, Ø., Harper, D.A.T., Ryan, P.D. (2001). PAST: Paleontological statistics software package for education and data analysis. Palaeontologia Electronica, 4(1):9pp. http://palaeo-electronica.org/2001_1/past/issue1_01.htm

[21] Santos, E. M., Almeida, A. V., \& Vasconcelos, S. D. (2004). Feeding habits of six anuran (Amphibia: Anura) species in a rainforest fragment in Northeastern Brazil. Iheringia. Série Zoologia, 94(4), 433-438.

[22] McKinney, M. L. (2002). Urbanization, Biodiversity, and Conservation. The impacts of urbanization on native species are poorly studied, but educating a highly urbanized human population about these impacts can greatly improve species conservation in all ecosystems. Bioscience, 52(10), 883-890.

[23] Parris, K.M., 2006. Urban amphibian assemblages as metacommunities. Journal of Animal Ecology, 75(3), 757-764.

[24] Zhang, W., Li, B., Shu, X., Pei, E., Yuan, X., Sun, Y., Wang, T. and Wang, Z. (2016). Responses of anuran communities to rapid urban growth in Shanghai, China. Urban Forestry \& Urban Greening 20, 365-374.

[25] Pillsbury, F. C., \& Miller, J. R. (2008). Habitat and landscape characteristics underlying anuran community structure along an urban-rural gradient. Ecological Applications, 18(5), 1107-1118.

[26] Kouamé, N. G., Ofori-Boateng, C., Adum, G. B., Gourène, G., \& Rödel, M. O. (2015). The anuran fauna of a West African urban area. Amphibian \& Reptile Conservation, 9(2), 1-14.

[27] Ferreira, R. B., Silva-Soares, T., \& Rödder, D. (2010). Amphibians of Vitória, an urban area in south-eastern Brazil: first approximation. Salamandra, 46(4), 187-196.

[28] Delima, E.M.M., Ates, F.B., Ibañez, J.C. (2006). Species composition and microhabitats of frogs within Arakan Valley Conservation Area, Cotabato, Mindanao Island, Philippines. BANWA, 3, 16-30.

[29] Matos, C., Sillero, N., \& Argaña, E. (2012). Spatial analysis of amphibian road mortality levels in northern Portugal country roads. Amphibia-Reptilia, 33(3-4), 469-483.

[30] Carr, L. W., \& Fahrig, L. (2001). Effect of road traffic on two amphibian species of differing vagility. Conservation Biology, 15(4), 1071-1078.

[31] Ates, F.B., Palafox, D.B., Cabelin, V.L.D., Delima, E.M.M. (2007) Diet Composition of Six Anuran Species (Amphibia: Anura) in Terminalia Forest, Mindanao Island, Philippines. BANWA Archives, 4(2), 7-20.

[32] Almeria, M. L., \& Nuñeza, O. M. (2013). Diet of seven anuran species (Amphibia: Anura) in Agusan Marsh, Mindanao, Philippines. Animal Biology \& Animal Husbandry, 5(1), 116-126.

[33] Toft, C. A. (1981). Feeding ecology of Panamanian litter anurans: patterns in diet and foraging mode. Journal of herpetology, 139-144.

[34] Apayor-Ynot, C.L., Tan, S.N., Kamyll, N. (2007). Diet of Cane Toads (Rhinella marina) collected from areas adjacent to human dwellings in Davao City, Philippines. Imperial Journal of Interdisciplinary Research, 3 (11), 640-642.

[35] Anderson, A. M., Haukos, D. A., \& Anderson, J. T. (1999). Diet composition of three anurans from the Playa Wetlands of Northwest Texas. Copeia, 515-520.

[36] Greenlees, M. J., Brown, G. P., Webb, J. K., Phillips, B. L., \& Shine, R. (2006). Effects of an invasive anuran [the cane toad (Bufo marinus)] on the invertebrate fauna of a tropical Australian floodplain. Animal Conservation, 9(4), 431-438.

[37] Greenlees, M. J., Brown, G. P., Webb, J. K., Phillips, B. L., \& Shine, R. (2007). Do invasive cane toads (Chaunus marinus) compete with Australian frogs (Cyclorana australis)?. Austral Ecology, 32(8), 900-907.

[38] Shine, R. (2010). The ecological impact of invasive cane toads (Bufo marinus) in Australia. The Quarterly Review of Biology, 85(3), 253-291.

[39] Janvic, M., The Philippine Star. (2019). No proof frogs, toads effective vs mosquitoes. Available at https://www.philstar.com/nation/2019/09/01/1948009/no-proof-frogs-toads-effective-vsmosquitoes\#XE1zYvSAMEB9j1S8.99. 